\title{
EMBLEMATY KULTURY POLSKIEJ Z PERSPEKTYWY CUDZOZIEMCÓW ${ }^{1}$
}

\begin{abstract}
Slowa kluczowe: kulturoznawstwo glottodydaktyczne, kultura polska, emblemat, perspektywa cudzoziemców

Streszczenie. Celem artykułu jest przedstawienie cudzoziemskiej recepcji cech i zjawisk polskiej lingwa- i socjokultury na podstawie analizy trzech książek-przewodników (S. Möllera 2006, L. Klos Sokol 2010, F. Vaucher 2016) oraz ocena przydatności tego typu źródeł w poszukiwaniu elementów typowych/charakterystycznych dla naszego portretu kulturowego. Analiza przedmiotowych materiałów była jednym z etapów badań (w ramach projektu Emblematy kultury polskiej - koncepcja leksykonu) nad różnymi perspektywami w postrzeganiu specyfiki szeroko rozumianej polskości, których poznanie jest niezbędne w pracach nad wydobywaniem i negocjowaniem zjawisk mogących uzyskać status emblematów polskiej kultury. Prezentowane rozważania dowodzą, że kluczową korzyścią płynącą z obserwacji i analizy doświadczeń obcokrajowców jest ich ,innowymiarowy" ogląd zjawisk, który wynika z zazwyczaj dobrze rozwiniętych sprawności interkulturowych. Cudzoziemcy mogą być cennymi mediatorami kulturowymi, zwłaszcza gdy w procesie oswajania się z innością odnoszą się do niej z humorystycznym dystansem, który sprzyja budowaniu pomostów między odmiennymi perspektywami i kształtowaniu postawy tolerancji.
\end{abstract}

\section{WPROWADZENIE - TLO I CEL ANALIZ}

Zainteresowanie innymi krajami i odmiennymi kulturami nie jest domeną współczesnej - zmediatyzowanej i zglobalizowanej - rzeczywistości, ale bez wątpienia $\mathrm{w}$ realiach cyfryzacji i globalizacji łatwiej jest zarówno prezentować kultury (narodowe i lokalne), jak i do takich kultur docierać oraz je poznawać.

*lumina@kul.pl; Katolicki Uniwersytet Lubelski Jana Pawła II, Wydział Nauk Humanistycznych, Katedra Języka Polskiego, Al. Racławickie 14, 20-950 Lublin.

${ }^{1}$ Niniejszy artykuł jest częścią dwugłosu z Beatą Kułak w związku z projektem Leksykonu emblematów kultury polskiej. Projekt i dyskusja nad pojęciem emblematu są przedstawione w artykule B. Kułak, natomiast w tym opracowaniu są prezentowane uwagi i refleksje ze wstępnego etapu badawczego do tegoż projektu, który wymagał m.in. weryfikacji cudzoziemskiego postrzegania naszej kultury. 
Oczywiste jest to, że jednym z narzędzi takiego poznawania i doświadczania jest język, za pomocą którego i poprzez który próbuje się pokazać oraz objaśnić to, co specyficzne, wyjątkowe, niepowtarzalne, emblematyczne ${ }^{2}$. Najpierw jednak tego typu elementy trzeba wydobyć i je nazwać - co jest przedmiotem zainteresowania różnych dziedzin, w tym lingwistyki, ale przykuwa również społeczną uwagę. A. Niewiara, analizując dotychczasowe badania nad poszukiwaniem wyrazów i fraz, które pomogłyby nam jako Polakom lepiej zrozumieć naszą wspólnotę, stwierdza, iż „o tym, że ciekawią nas polskie słowa i polskie zdania, przekonują zarówno popularne quizy na najpiękniejsze polskie słowo, dziwne polskie słowa i zdania, jak i prace naukowe. W polskiej lingwistyce kulturowej i aksjologii lingwistycznej ostatnich dwudziestu lat znajdziemy kilka propozycji ustalających zestaw polskich słów (=polskich wartości) albo polskich zdań / skrzydlatych słów wykorzystywanych w interpretacji polskiej kultury" (Niewiara 2014, s. 65) ${ }^{3}$. Jednak mimo tworzenia zestawów, o których wspomina A. Niewiara, oraz podejmowania różnych prób opracowania słowników, nie udało się do tej pory przygotować i wydać żadnego leksykonu o charakterze stricte glottodydaktycznym ${ }^{4}$, czyli takiego, który służyłby wyjaśnianiu polskiej kultury (nie tylko w jej werbalnej reprezentacji) obcokrajowcom z uwzględnieniem praktyki językowo-komunikacyjnej. Tymczasem potrzeba opracowania takiej publikacji czy też interaktywnej platformy systematycznie wzrasta wraz ze zwiększającą się od kilku lat liczbą uczących się języka polskiego jako obcego ${ }^{5}$. Prezentacji nowej inicjatywy - projektowi Leksykonu emblematów kultury polskiej oraz wstępnym propozycjom jego wykorzystania w praktyce glottodydaktycznej - poświęca swój tekst Beata Kułak. Niniejszy artykuł opisuje tę część badawczą ww. projektu, która była poświęcona kwestii weryfikacji materiału źródłowego niezbędnego do wypracowania narzędzia mogącego wspierać cudzoziemców w „otwieraniu” różnych sfer polskiej lingwa- i socjokultury (por. Zarzycka 2004).

Eksplorowanie źródeł i ustalanie kluczowych pojęć w badaniach lingwai socjokulturowych opartych na metodach etnolingwistyki nazywane jest w najnowszej literaturze przedmiotu typowaniem (Rak 2015) lub wydobywaniem (Zarzycka 2019) kulturemów ${ }^{6}$. Jedną ze strategii tej eksploracji w odniesieniu do kulturemów polskości jest badanie perspektywy cudzoziemców, którzy mieli okazję doświadczyć polskiej kultury i być może także w jakimś stopniu się z nią

${ }^{2}$ Por. „(...) pojęcia danego języka mogą stanowić przewodnik i pokazywać, jak dana grupa kulturowa kategoryzuje świat. Każda treść kultury daje się zawsze wyrazić w języku" (Kajak 2020, s. 21; podkreślenie moje).

${ }_{3}$ Autorka ma na myśli zbiory przygotowane przez Jerzego Bralczyka (2004, 2005, 2006, 2007). W jej artykule zawarte jest krótkie omówienie tych publikacji.

${ }^{4}$ Próbie opracowania takiego leksykonu poświęca swój artykuł B. Kułak.

${ }^{5}$ Tego typu narzędzie miałoby nie mniejszą wartość w praktyce przekładu. Więcej na temat zob. np. Ornat 2013.

${ }^{6} \mathrm{Na}$ temat rozumienia terminu kulturem pisze B. Kułak. 
oswoić. Jak stwierdza G. Zarzycka, „kulturemy polskie nie są »własnością« jedynie Polaków. Żeby je wydobyć i właściwie zinterpretować, potrzebne jest skrzyżowanie perspektyw (...) - spojrzenie na Polaków i świat Polaków oczami nie-Polaków i skonfrontowanie tych wyobrażeń i sądów z sądami »swojaków «, jak też z naszą własną, indywidualną opinią na dany temat" (Zarzycka 2019, s. 429). Istotną korzyścią płynącą z poznawania i analizy doświadczeń obcokrajowców w zakresie naszej kultury jest ,innowymiarowy” ogląd zjawisk wynikający często $z$ dobrze rozwiniętych sprawności interkulturowych cudzoziemców, takich jak dostrzeganie związku między kulturą własną a kulturami obcymi, pośredniczenie między kulturami czy radzenie sobie z barierami interkulturowymi ${ }^{7}$. Cudzoziemcy cechujący się wysoką wrażliwością interkulturową są w stanie zwrócić uwagę na aspekty, które z perspektywy tubylców wydają się drugorzędne lub odwrotnie - mogą „detronizować” własnym spojrzeniem emblematyczność rzeczy, faktów czy zjawisk uznawanych przez nosicieli danej kultury za najbardziej dla niej reprezentatywne.

Badania nad „obcokulturowym” spojrzeniem na wybrane elementy naszej rzeczywistości kulturowej - stosując różne metody i techniki badawcze - podejmowali dotychczas m.in. P. Gębal (2005), G. Zarzeczny i T. Piekot (2010), P. Chojnowski (2012), A. Stepień i P. Kajak (2016) czy G. Zarzycka (2019). Badacze ci zajmowali się obserwacją negocjowania ${ }^{8}$,miejsc znaczących" podczas różnego typu konfrontacji treści polskiej kultury w swojej praktyce glottodydaktycznej, jak również poznawaniem i ustalaniem potrzeb oraz oczekiwań cudzoziemców odnośnie do treści kulturowych, które są im prezentowane w materiałach dydaktycznych. Głównym celem moich rozważań jest przedstawienie cudzoziemskiej recepcji polskich cech i zjawisk lingwa- i socjokulturowych na podstawie analizy trzech publikacji: 1) Stefana Möllera Polska da się lubić. Mój prywatny przewodnik po Polsce i Polakach, 2) Laury Klos Sokol Shortcuts to Poland oraz 3) Fanny Vaucher Pilules polonaises oraz ocena przydatności tego typu źródeł w poszukiwaniu elementów znamiennych dla naszego portretu kulturowego. Wymienionych autorów różni pochodzenie (odpowiednio są to Niemiec, Amerykanka i Szwajcarka) oraz języki narracji, ale łączy ich formuła prezentacji swoich sądów i opinii, utrzymanych w stylistyce przewodnika czy też poradnika napisanego - w mniejszym lub większym stopniu - z przymrużeniem oka ${ }^{9}$.

${ }^{7}$ Na temat umiejętności interkulturowych zob. ESOKJ 2003, s. 94-99.

${ }^{8}$ O negocjowalności jako istotnej cesze kulturemów pisze Zarzycka (2019).

${ }^{9}$ Wybrane książki to oczywiście nie jedyne opublikowane „głosy” cudzoziemców w sprawie tego, co może stanowić emblematy polskiej kultury. Inne publikacje - zasługujące na osobne omówienie - to np. Amsellem (2006), Augustynowicz (2017), Fosso (2001), Schulze, Gawin (2015), Swan (2014). 


\section{OMÓWIENIE ANALIZOWANYCH ŹRÓDEŁ}

\subsection{STEFFEN MÖLLER, POLSKA DA SIE LUBIĆ. MÓJ PRYWATNY PRZEWODNIK PO POLSCE I POLAKACH ${ }^{10}$}

Polska da się lubić to pozycja zawierająca najobszerniejszy - spośród analizowanych tu źródeł - materiał polonoznawczy. Autor tej publikacji jest Niemcem, w latach 1994-2010 pracował jako lektor języka niemieckiego w jednym z warszawskich liceów oraz na Uniwersytecie Warszawskim (wcześniej, podczas studiów, był też w Krakowie na kursie języka polskiego). W tym czasie stał się postacią medialną i zdobył sympatię Polaków dzięki udziałowi w programie telewizyjnym Europa da się lubićn ${ }^{11}$, w którym ujawnił nie tylko swoje humorystyczne spojrzenie na świat, ale i naturę bacznego obserwatora europejskiej rzeczywistości społeczno-kulturowej. Od 2010 r. co miesiąc podróżuje w sprawach zawodowych między Berlinem a Warszawą ${ }^{12}$. Wieloletnie doświadczenie codziennego życia i pracy w polskich realiach zaowocowało m.in. wydaniem omawianej publikacji ${ }^{13}$. Warto zaznaczyć, że S. Möller poznał Polskę zarówno tę sprzed przełomu ustrojowego 1989 r., jak i obserwował zachodzące w niej zmiany po przełomie oraz po wejściu do Unii Europejskiej w 2004 roku. Dało mu to możliwość szerokiego oglądu naszej kultury i zauważenia tego, co w niej jest stałe, a co podlega zmianom wskutek różnego typu zewnętrznych czynników. Nie bez znaczenia jest również humanistyczne, w tym filologiczne przygotowanie autora, które z pewnością miało duży wpływ na jego wrażliwość kulturową oraz dociekliwość poznawczą - zwłaszcza w kwestiach dotyczących systemu polszczyzny z perspektywy uczącego się jej cudzoziemca.

${ }^{10}$ Niemieckojęzyczna wersja książki została wydana w 2009 r. pod tytułem Viva Polonia. Als deutscher Gastarbeiter in Polen, natomiast w roku 2013 ukazało się wydanie w języku angielskim Expedition to the Poles.

${ }^{11}$ Pozyskał też rolę jednej z postaci w popularnym serialu M jak Miłość. Więcej informacji na temat autora i obszarów jego aktywności zawodowej zob. http://www.steffen.pl [09.04.2020].

${ }^{12}$ Publikacją dokumentującą doświadczenia Möllera z tych podróży jest książka Berlin - Warszawa - Express. Pociag do Polski, która ukazała się także po niemiecku. Ostatnia wydana książka autora ukazała się w 2019 r., nosi tytuł Weronika, twój mąż tu jest! - Gdy Niemcy i Polacy się kocha$j q$ i jest poradnikiem małżeńsko-rodzinnych relacji w związkach mieszanych.

${ }^{13}$ Por. fragment wywiadu z Möllerem: „Doświadczenie Polski niesamowicie mnie wzbogaciło. Inaczej dzisiaj patrzę na Niemcy, na siebie samego. Troszkę ubolewam, że obecnie wszystko tak zdominowały tematy polityczne. Moje zainteresowania są na niższym szczeblu. Takim interkulturowym. Sprawy międzykulturowe to jakby fundament. One istnieją zawsze, niezależnie od polityki”. https://viva.pl/ludzie/newsy/steffen-moller-co-robi-teraz-czy-wroci-do-europa-da-sie-lubic-121028-r1/ [09.04.2020]. 
We wstępie S. Möller pisze m.in.:

\begin{abstract}
Obserwowałem Polaków na weselach, w windzie i na wakacjach od Rzeszowa po Szczecin, spędzając przy tym niemało czasu w wagonach WARS-u. [...] Zamierzam w tej książce dowieść, że Polacy mają największy skarb na świecie. Nie chodzi jednak ani o piękne zamki, ani o wyśmienitą kuchnię, ani o piękne krajobrazy. To jest lepsze w Szwajcarii, w Stanach, w Anglii, we Francji albo we Włoszech. Mnie chodzi o Polską duszę lub - mówiąc bardziej nowocześnie - o polską mentalność.
\end{abstract}

(Möller 2006, s. 7)

Opisując polską mentalność, autor nie ogranicza się jednak wyłącznie do tych zagadnień, które są ściśle związane z naszą narodową „filozofią”. W pięćdziesięciu dziewięciu (poza wstępem i epilogiem) alfabetycznie ułożonych i pełnych humoru esejach prezentuje rozmaite aspekty polskości: nasze obyczaje i cechy narodowe, kulturę, sztukę, ale też życie codzienne w rozmaitych sytuacjach. Spis treści jest ułożony alfabetycznie, co sprawia, że otrzymujemy zestaw zagadnień traktowanych przez autora jako prywatny „alfabet Möllera”. Tytuły rozdziałów są w większości jednowyrazowe, np. Anarchia, Ciekawość, Komplementy, Wolność, ale zdarzają się też frazy, np. Chicago - amerykanizacja, Kobieta w autobusie, Moja wizja Europy, Telefoniczne obyczaje. Niektóre z nich są łatwe do odczytania w zakresie podejmowanej tematyki (np. Gościnność, Imiona, Zdrobnienia), inne można zrozumieć dopiero po zapoznaniu się z zawartością (werbalną i ikoniczną) danego rozdziału (np. Bawić się, Lekkość, $\mathrm{Na}$ celowniku). Narracjom autora towarzyszą liczne zdjęcia z jego prywatnego archiwum oraz marginalnie zamieszczane „uwagi poboczne” uporządkowane w trzech kategoriach komentarzy: 1) A tak na marginesie, 2) Co mi się w Polsce podoba; 3) Co mi się w Polsce mniej podoba. Każdy z wymienionych komponentów przewodnika Möllera jest znaczący z tego względu, iż w każdym z nich ujawnia się kunszt autora występującego w roli świadomego mediatora kulturowego - gotowego także do tego, aby otwarcie mówić o nabywaniu tej umiejętności. W eseju zatytułowanym Polak prywatny i publiczny Möller pisze m.in.:

Myślałem, że Polacy to Włosi północy, a okazało się, że są ponurakami jak Finowie, którzy potrafią się wyluzować dopiero wieczorem po imprezie, za pomocą alkoholu, Miałem wątpliwości, czy wytrzymam w takim kraju dłużej niż dwa miesiące. (...) No, i wreszcie wpadłem na rozwiązanie. Polacy są jak Finowie, owszem - ale tylko w stosunku do obcych. W gronie znajomych lub krewnych Polacy są Włochami! Dzisiaj wiem, że prawdziwy polski temperament ujawnia się dopiero w kręgu najbliższych, na imprezie po godzinie dwudziestej drugiej.

(Möller 2006, s. 79)

Równie istotne dla zrozumienia elementów eksplikujących polskość w publikacji Niemca są: wybór opisywanych wycinków rzeczywistości (znacznie częściej tej codziennej, „ulicznej” niż należącej do dziedzictwa kultury wysokiej), rzetelność w relacjonowaniu faktów (wynikająca $\mathrm{z}$ wieloletniego pobytu 
w Polsce i autorskiej dokumentacji fotograficznej) czy sposób, w jaki są one prezentowane - nawet w kwestiach trudnych z szacunkiem dla odmienności innej kultury i humorem łagodzącym kwestie zaskakujące lub kontrowersyjne dla obcokrajowca. Charakteryzująca Möllera postawa otwartości wyklucza negację inności, z tego względu w jego zapiskach - poza wymienionymi wyżej marginaliami - nie ma uwag nawiasowych pt. Co mi się w Polsce nie podoba (podkreślenie moje).

Żaden z rozdziałów nie jest osobno poświęcony polszczyźnie, hasło język polski występuje jako podrozdział w części zatytułowanej Trzy prztyczki, ale uwagi dotyczące specyfiki naszego języka pojawiają się w różnych miejscach książki i w większości mają charakter żartobliwych „prztyczków” pod jego adresem. Möller pisze m.in.

Wcale mnie nie dziwi, że polscy uczniowie i studenci zajmują pierwsze miejsca w mate-
matycznych oraz informatycznych konkursach na całym świecie. Jak może być inaczej
skoro od drugiego roku życia opanowują do perfekcji tak trudny język? Raczej dziwię
się, że policja jeszcze nie interweniowała. Czy to nie skandal, że niepełnoletnie dzieci
zmusza się w Polsce do bezbłędnej kombinacji paruset gramatycznych odmian na godzi-
nę? To nie jest przesada kabareciarza. Policzmy konkretnie. Każdy rzeczownik polski
ma końcówki w 7 przypadkach w liczbie pojedynczej i mnogiej. To w sumie 14 wer-
sji tego samego słowa. Weźmy też na przykład niewinne słowo mężczyzna. Niewinne?
Niewinnych słów istnieje w polskim szalenie mało. Słowo mężczyzna jest dziwacznym
wyjątkiem, bo odmienia się jak rzeczownik rodzaju żeńskiego, chociaż jest mężczyzną!

(Möller 2006, s. 112)

Warto zauważyć, że „narzekając” na uciążliwość systemu polszczyzny, autor przekazuje przy okazji uporządkowane dane i informacje gramatyczne. Dzięki temu kształtuje świadomość językową w zakresie specyfiki języka polskiego nie tylko u obcokrajowców, ale i w kręgu rodzimych użytkowników języka polskiego ${ }^{14}$. Stara się także, aby utyskiwanie na zawiłości naszego języka było okazją do zwrócenia uwagi na znaczące dla naszej kultury fakty czy postaci, por.

Powiem bardzo krótko: wszystkim sfrustrowanym obcokrajowcom na polskich kursach językowych wydaje się, że prawdopodobieństwo prawidłowej konstrukcji chociażby jednego prymitywnego zdania wydaje się być równe możliwości wygrania jack-potu w totolotku, czyli wynosi ono jeden do trzynastu milionów. Powodzenia! Ja osobiście nigdy się więc nie dziwiłem, że akurat polscy matematycy złamali kod słynnej Enigmy!

(Möller 2006, s. 112)

Publikacja Polska da się lubić w całości jest nacechowana „klimatem” adekwatnym do tezy zawartej w tytułowym stwierdzeniu, dzięki czemu lektura tego przewodnika faktycznie zachęca do poznawania polskości i oswajania się z nią.

${ }^{14}$ Regularnie korzystam z fragmentów omawianej książki na zajęciach dla studentów specjalizacji glottodydaktycznej w celu uzmysłowienia im m.in. tego, w jaki sposób cudzoziemiec odbiera system gramatyczny naszego języka. 
Książka S. Möllera udowadnia również, że cudzoziemców interesują bardzo różne dziedziny i aspekty życia Polaków, ich historii oraz kultury - zarówno narodowej, jak i tej lokalnej. Spojrzenie na polską rzeczywistość przez filtr humoru pozwala mówić autorowi o dziwnych, a nawet trudnych sprawach i nie urazić naszej narodowej dumy.

\title{
2.2. LAURA KLOS SOKOL, SHORTCUTS TO POLAND ${ }^{15}$
}

Laura Klos Sokol to Amerykanka, która w 1992 r. przyjechała do Polski w ramach stypendium Fulbrighta. Planowała roczny pobyt, ale wyszła za mąż za Polaka i została u nas na stałe. Jej publikacja jest anglojęzyczna, miała już cztery wydania (pierwsze w 1997 r., następne dwa w 2005 i 2010 r., ostatnie zaś w 2015 r.), nie doczekała się jednak na razie tłumaczenia na język polski. Kolejne odstępy czasowe pomiędzy wydaniami pozwoliły autorce na wieloletnie obserwacje naszej rzeczywistości oraz zmian zachodzących w Polsce $\mathrm{w}$ tym czasie ${ }^{16}$. Z tego powodu w swoich opisach jest świadoma, że prezentuje stan faktyczny w danym momencie, który za kilka lat może być już nieaktualny.

Książka Sokol została pomyślana jako specyficzny poradnik dla Amerykanów przyjeżdżających do Polski czy rozpoczynających życie w naszym kraju. Na okładce czytamy:

\begin{abstract}
Niezależnie od tego, czy odwiedzasz Polskę czy tu pracujesz, ta książka pomoże ci lepiej zrozumieć codzienne zachowania Polaków - a być może niektóre z twoich własnych w sytuacji komunikacji międzykulturowej. Nie skupiając się tylko na pierogach czy wódce, nauczysz się prowadzić rozmowę, zachowywać jako gość, być dobrym współpracownikiem i nawiązywać przyjaźnie. Spostrzeżenia kulturowe na temat polskich zachowań sprawią, że poczujesz się bardziej komfortowo w Polsce... lub przynajmniej będziesz mniej zaskoczony. Skierowane do Amerykanów przykłady i obserwacje przypadną do gustu wszystkim zainteresowanym komunikacją międzykulturową.
\end{abstract}

(Klos Sokol 2010, okładka)

Tak sformułowane streszczenie książki wyraźnie odsłania charakter zamieszczonych w niej uwag, porad i spostrzeżeń - ze względu na użytkowe (adaptacyjne) ukierunkowanie dotyczą one przede wszystkim tego, co jest charakterystyczne w domowej, towarzyskiej i zawodowej codzienności Polaków. Istotna jest tu oczywiście perspektywa międzykulturowa, ponieważ typowość omawianych

${ }^{15} \mathrm{~W}$ wolnym thumaczeniu polski tytuł można sformułować Na skróty do Polski. Wszystkie cytowane fragmenty tej publikacji są w tłumaczeniu własnym i pochodzą z 3. wydania książki.

${ }^{16}$ W wywiadzie z 2011 r. dla radiowej „Trójki” Klos Sokol stwierdziła m.in.: „Przez ostatnie 15 lat Polacy bardzo się zmienili. Różnicę między starszymi a młodymi widać w podejściu do pracy, zachowaniu, a nawet sposobie odbierania krytyki" https://www.polskieradio.p1/9/396/Artykul/336074,Dwa-polskie-swiaty-okiem-obcokrajowca [30.03.2020]. 
zdarzeń, zachowań czy sytuacji Klos Sokol odkrywa poprzez ich konfrontację z nawykami i zwyczajami Amerykanów.

Treści „skrótów do Polski” zostały uporządkowane przez autorkę w pięciu rozdziałach. Pierwszy z nich, zatytułowany Wybrane zachowania, zawiera dwadzieścia sześć zagadnień, w których Klos Sokol przedstawia swoje spostrzeżenia dotyczące zachowań Polaków w relacjach społecznych, przykładowo: prezentuje reakcje Polaków na pytanie „Co słychać?”, wyjaśnia różnice w byciu przyjacielem, kolegą, kumplem lub znajomym, pisze o „otwartym” prowadzeniu sporów przez Polaków czy tłumaczy jedną z fundamentalnych zasad polskiej grzeczności wyrażonej w przysłowiu Gość w dom, Bóg w dom. Kolejna część obejmuje siedem esejów z zakresu zawodowego życia polskiego społeczeństwa, przede wszystkim tego, które toczy się w międzynarodowych korporacjach (ich realia Klos Sokol poznała najlepiej). Autorka porusza tu na przykład kwestię stosunku młodego pokolenia Polaków do kariery zawodowej po przełomie 1989 r. czy też specyfikę polskich zachowań w sytuacjach kryzysowych w pracy oraz miejsca aktywności zawodowej w hierarchii wartości Polaków. Dwanaście esejów włączonych do rozdziału Polska specyfika to refleksje autorki m.in. na temat stosunku Polaków do kwestii wieku, relacji rodzinnych, funkcjonowania pewnych społecznych modeli osobowych (np. Matka Polka, urzędas, cieć, stara baba, dziad) oraz inne aspekty dotyczące naszej obyczajowości. Spostrzeżenia z tego obszaru znajdują się też w kolejnej części zatytułowanej Inne ciekawostki, w której Amerykanka zamieściła np. rozważania na temat funkcjonowania małżeństw mieszanych, pozawerbalnych konwencji polskich powitań, zachowań Polaków związanych z ich pupilami, ale też uwagi dotyczące naszej biurokracji. Natomiast rozdziałem wieńczącym jest wypełniona czternastoma opowiastkami część, której tytuł można przetłumaczyć jako Wsparcie językowe lub Pogotowie językowe ${ }^{17}$. Odnajdujemy tu humorystyczne rozważania m.in. na temat fleksji i składni polskich liczebników, potocznych fraz typu trele-morele czy gadka-szmatka, bogactwa i finezji polskich toastów, różnorodności oraz „wylewności” formuł powitań i pożegnań ${ }^{18}$ czy też wskazówki z zakresu etykiety językowej (np. kiedy wypada zwracać się per ty i jaki związek ma z tym bruderszaft). W tej części osobnym rozdzialikiem jest esej The Polglish Language. Tak sformułowany tytuł nie jest ani pomyłką edytorską, ani błędem autorki, ale dowodem jej świadomości językowej i hasłem „mówiącym” dla jej rozważań. Amerykanka porusza tu bowiem kwestię zjawiska mieszania polszczyzny z angielszczyzną (w różnych formach), zwłaszcza w realiach pracy w zagranicznych korporacjach. Było to zjawisko, które stało się znamienne dla naszej komunikacji językowej po przełomie ustrojowym w 1989 roku. I właśnie przez pryzmat znamion tamtego okresu Klos

${ }^{17}$ Tytuł oryginalny: A Language Booster.

${ }^{18}$ Por. następujące stwierdzenie: „Gdyby pożegnania były muzyką, Amerykanie zagwizdaliby prostą melodię, a Polacy wykonaliby całą symfonię" (ang. "If good-byes were music, Americans would whistle a simple tune and Poles would play a five-part harmony") (s. 163). 
Sokol otwiera przez swoimi rodakami specyfikę języka polskiego: zwraca uwagę m.in. na wchodzące wówczas do polszczyzny korporacyjnej nazwy i frazy typu: dział marketingu, dzwonić na helpdesk, zrób mi update, mam deadline itp.; przytacza opinię lingwisty Jana Wawrzyniaka na temat ekspansji słowa menedżer, które wyparło kierownika; przy okazji pisze także o zmianach w obyczajowości na przykładzie wkraczającego do polskich realiów lunchu. Co najważniejsze, autorka prezentuje wszystkie te kwestie nie po to, aby pokazać ich dziwaczność (i przez to chociażby deprecjonować zachowania językowe Polaków), przeciwnie - neutralizuje ich potencjalnie szokujący charakter poprzez odniesienie do uniwersalnych, międzykulturowych fenomenów, jakimi są przenikanie się różnych języków, zapożyczenia międzyjęzykowe czy mieszanie kodów językowych, por.

»I have małe pytanie« - mówi Amerykanin do swojego polskiego kolegi z pracy. »Muszę wziać ten ticket « - mówi pracownik biura turystycznego do swojego współpracownika. »Sorry« - mówi polski piłkarz do kolegi z drużyny po tym, jak nie zdołał odebrać jego podania. »Było super« - stwierdza Polak po imprezie. Boże! To znaczy, God! Co się dzieje z tymi ludźmi? Czy oni nie potrafią normalnie mówić? No nie. I nie ma w tym nic dziwnego. Akceptujemy to lub nie - mieszanie języków jest naturalnym zjawiskiem. Są nawet na to nawet specjalistyczne nazwy, kiedy mówiący posługują się taką hybrydową komunikacją poprzez krzyżowanie języków: przełączanie kodów (code-switching), mieszanie kodów (code-mixing) i zapożyczenia (borrowings).

(Klos Sokol 2010, s. 177)

Poza wymienionymi wyżej rozdziałami autorka zamieściła w swoim poradniku także dwa kwizy: The Polskość Quiz, czyli „kwiz na polskość”, oraz The American Quiz, czyli „kwiz na amerykańskość”. Są to bardzo interesujące komponenty tej publikacji, szczególnie wartościowe dla badań nad cudzoziemskim spojrzeniem na daną kulturę. Kwiz na polskość to przede wszystkim cenny dokument specyfiki polskiej socjokultury lat 90 . XX w. - i jej osobliwości takich, jak rozkładane półkotapczany w polskich domach, ciasnota w mieszkaniach czy królujący na polskich ulicach mały fiat - ale także zjawisk bardziej trwałych kulturowo, o czym świadczą przykładowo następujące pytania:

Czy lubisz prince polo albo ptasie mleczko?

Czy twoje nazwisko składa się z co najmniej 3 sylab?

Kiedy przychodzi do ciebie gość, czy od razu proponujesz mu coś do picia?

Czy chodzisz do kościoła we wszystkie święta kościelne?

Formułę kwizu zaproponowanego przez Klos Sokol należy uznać za inspirującą do wykorzystania jej jako narzędzia do „wyławiania” zjawisk reprezentatywnych, a następnie selekcjonowania tego, co jest charakterystyczne dla jakiegoś okresu, a co można traktować jako emblematyczne w sensie uniwersalnym dla danej kultury ${ }^{19}$.

${ }^{19} \mathrm{Na}$ temat wykorzystania tego quizu do weryfikacji jego potencjału kulturemowego z perspektywy polskich i zagranicznych studentów, zob. Zarzycka 2019. 
Shortcuts to Poland to publikacja ukazująca erudycję autorki oraz jej niezwykły, okraszony poczuciem humoru, takt interkulturowy. Odsłaniając kulisy codziennego życia Polaków, Klos Sokol udowadnia, że są one warte uwagi dla cudzoziemców nie jako ,podwórkowe ciekawostki” (które notabene mogą stać się poważnymi barierami komunikacyjnymi), ale jako rzetelne dane potrzebne w kulturowej adaptacji. Amerykankę cechuje też mądre podejście do stereotypów - jej spojrzenie na nasze realia może w wielu aspektach uczyć zrozumienia polskiej kultury czy rewizji poglądów na jej temat nie tylko Amerykanów, ale i samych Polaków.

\subsection{FANNY VAUCHER, PILULES POLONAISES $S^{20}$}

Autorka tej książki to Szwajcarka, absolwentka Uniwersytetu Lozańskiego oraz Genewskiej Szkoły Sztuki Użytkowej. Zajmuje się zawodowo ilustracją i komiksem - współpracuje z fanzinami poświęconymi sztuce komiksowej. W latach 2010-2015 prowadziła francuskojęzycznego bloga o Warszawie ${ }^{21} \mathrm{i}$ te zapiski stały się podstawą pierwszego wydania Pigułek. Tytuł swojej pozycji Vaucher wyjaśnia następująco:

Przy przeprowadzce ze Szwajcarii do Warszawy wzięłam ze sobą pigułki przeciwbólowe - były biało-czerwone, zupełnie jak flaga Polski. Do dziś ich nie zużyłam, więc rok spędzony tutaj nie był aż tak bolesny.

(Vaucher 2016, okładka)

Pilules polonaises to trójjęzyczna (francusko-polsko-angielska) publikacja wydana w formie bogato ilustrowanej kroniki, w której autorka dokumentuje swoje refleksje i spostrzeżenia dotyczące polskich realiów społeczno-kulturowych. Wydanie książkowe bliskie jest pierwotnemu formatowi zapisków Vaucher - poszczególne tematy nie są uporządkowane według jakiegoś konkretnego klucza, stanowią zbiór swobodnych refleksji, tak jak wpisy na blogu. Pod koniec 2013 r. ukazało się pierwsze wydanie, obejmujące lata 2012-2014 i przedstawiające kulturowe ciekawostki z Warszawy, wydanie drugie z 2016 r. (Pilules polonaises 2) zostało rozszerzone o dane $\mathrm{z}$ innych miejsc w Polsce, choć nadal najwięcej informacji dotyczy naszej stolicy. We wprowadzeniu do drugiego wydania autorka zwraca uwagę na kwestie istotne dla postrzegania realiów z perspektywy cudzoziemca, który przebywa już w danej kulturze jakiś czas i obserwuje ją $\mathrm{z}$ uwagą, dokumentując zachodzące $\mathrm{w}$ niej przemiany:

${ }^{20}$ Polskojęzyczna wersja tytułu: Polskie pigułki. Cytaty, które zamieszczam w artykule, pochodzą z 2. wydania (2016 r.) tej publikacji.

${ }^{21} \mathrm{http} / / /$ pilulespolonaises.blogspot.com/ [20.03.2020]. 
(...) W Warszawie, która jest sercem tej akwarelowej przygody, wszystko pędzi sto kilometrów na godzinę i tyle już zdążyło się zmienić, na lepsze lub gorsze. Tyle opisanych w książce - i lubianych miejsc pozmieniało się albo poznikało, jak chociażby dom handlowy Sezam w centrum Warszawy albo dworzec Łódź Fabryczna. Tak to już bywa! Jestem więc podwójnie szczęśliwa, że te miejsca będą mogły w jakiś sposób żyć dalej - na papierze.

(Vaucher 2016, s. 4)

Jakie tematy autorka Polskich pigułek włączyła do swojego oryginalnie ilustrowanego subiektywnego przewodnika ${ }^{22}$ ? Podobnie jak w przypadku wcześniej omawianych pozycji, mamy tu wybór rozmaitych zagadnień: językowych, kulinarnych, obyczajowych, pogodowych, mentalnych oraz faktograficznych. Ten zestaw obszarów zainteresowania raczej nie jest zaskakujący, natomiast najcenniejszy jest sposób jego prezentacji oddający perspektywę Szwajcarki w polskim otoczeniu, np. jej zaskoczenie, że w Wiśle nie można pływać, że bary mlecze nie koncentrują się w rzeczywistości na daniach wyłącznie mlecznych czy zdziwienie, że Polacy świętują i urodziny, i imieniny. Warte uwagi jest to, iż w odkrywaniu i poznawaniu polskich znaczeń oraz oswajaniu się z nimi najważniejsze dla autorki były nie symbole i miejsca pokazywane w większości tradycyjnych przewodników, ale emblematy bardziej codziennych doświadczeń. Wszystko to stwarza bardzo dobrą platformę do konfrontowania sądów i przyzwyczajeń polskiego tubylca.

W przeciwieństwie do S. Möllera i L. Klos Sokol „hasła” swojego przewodnika F. Vaucher sformułowała nie w postaci wyrazów czy wyrażeń, ale w formie pytań $^{23}$, których w analizowanych wydaniu jest czterdzieści pięć. Przyjęcie takiej konwencji hasłowania jest wartościowo poznawcze, ponieważ odkrywa mechanizmy patrzenia na polską rzeczywistość oczami cudzoziemca, dla którego nasze „oczywistości” (prawdopodobnie niezauważane na co dzień i niepostrzegane jako godne uwagi) są nieoczywistymi „miejscami znaczącymi”. Wiele z pytań rozpoczyna się słówkiem pytającym dlaczego, np.

Dlaczego Polacy sa romantykami?

Dlaczego w Łodzi jest tyle pustostanów?

Dlaczego bociany tak lubia Polskę?

Dlaczego Czarna Madonna jest czarna?

${ }^{22}$ Strona graficzna książki nie jest w tym artykule najważniejszym przedmiotem zainteresowania, ale warto wspomnieć o jej wyjątkowej formie: ilustracje są szkicowane piórkiem i podkolorowywane akwarelą, są odręczne i publikowane bez komputerowej obróbki, co w dzisiejszych czasach jest rzadkością. Są one również bardzo dobrze skomponowane, miejscami przybierają postać komiksu.

${ }^{23} \mathrm{~W}$ tym miejscu chcę zaznaczyć, że pomysł na formułowanie haseł Leksykonu emblematów kultury polskiej w formie pytań zrodziło się niezależnie od publikacji F. Vaucher, ale jej książka umocniła podjętą decyzję. 
Rany boskie, dlaczego ludzie daja kwiaty ósmego marca?

Dlaczego w lipcu tyle pada?

Ale są także zagadnienia, które wzbudziły zaciekawienie Szwajcarki z innej perspektywy i w odniesieniu do nich autorka stawiała inaczej sformułowane pytania, w których ujawnia się potencjał dyskusyjności (negocjowalności) określonych sądów i spostrzeżeń, np.

Gdzie sa niegdysiejsze śniegi?

Pije jak...?

Skąd się biora wzgórza w płaskim mieście?

Jak poznać, że jesteśmy w polskiej kuchni?

Czekaj, pozwól mi zgadnać... teraz robi się przetwory, tak?

Czy rynek Starego Miasta jest poprawny politycznie?

Forma pytania jako hasła w przewodniku kulturowym ma więc z perspektywy badawczej ten walor, że nie ogranicza zakresu odniesień do danego faktu, otwiera przestrzeń skojarzeń i pole do dyskusji, co jest bardzo ważne, kiedy w procesie konfrontacji poszukuje się miejsc znaczących. Warto uświadomić sobie także fakt, że pytania w Polskich pigułkach stawia nie cudzoziemiec z innego, odległego kontynentu, ale mieszkanka europejskiej wspólnoty kulturowej - w sytuacji otwarcia granic europejskich krajów oraz w dobie mnożących się w internecie informacji turystycznych, polityczno-gospodarczych, społecznych itd. można by zakładać, że wzajemne poznawanie (się) Europejczyków nie powinno ujawniać już tak licznych zaskoczeń. Tymczasem doświadczenia F. Vaucher pokazują, po pierwsze, że tak nie jest, po drugie - że najbardziej zaskakujące mogą być właśnie codzienne doświadczenia, w związku z czym również współczesnym młodym generacjom - pokoleniom cyfrowych tubylców - dobrze przemyślane eksplikacje kulturowe nadal są potrzebne.

Krótkie formy narracyjne lub dialogowe typowe dla wpisów F. Vaucher nie pozwoliły jej na zamieszczanie w Pigułkach dłuższych passusów czy rozbudowanych refleksji na temat jej stosunku do polszczyzny (nie wiemy zresztą, czy chciałaby o tym więcej pisać). Jednak pewną odsłonę swojego postrzegania polszczyzny Szwajcarka ujawnia we wpisie zatytułowanym Kto powiedzial, że „, Ten, kto potrafi wszystko wycierpieć, na wszystko się odważy”?24. Rozwinięciem tego hasła jest krótka rozmowa między Francuzką a Polakiem, w której autorka w humorystycznym tonie odnosi się do niełatwej dla cudzoziemca polskiej fonetyki, por.

${ }^{24} \mathrm{Na}$ stronie tego hasła jest też zamieszczona (zapisana „do góry nogami”) następująca odpowiedź: „Markiz de Vauvenargues, który, tak się złożyło, pojechał na wojnę do Polski na początku XVIII wieku" (Vaucher 2016, s. 77). 


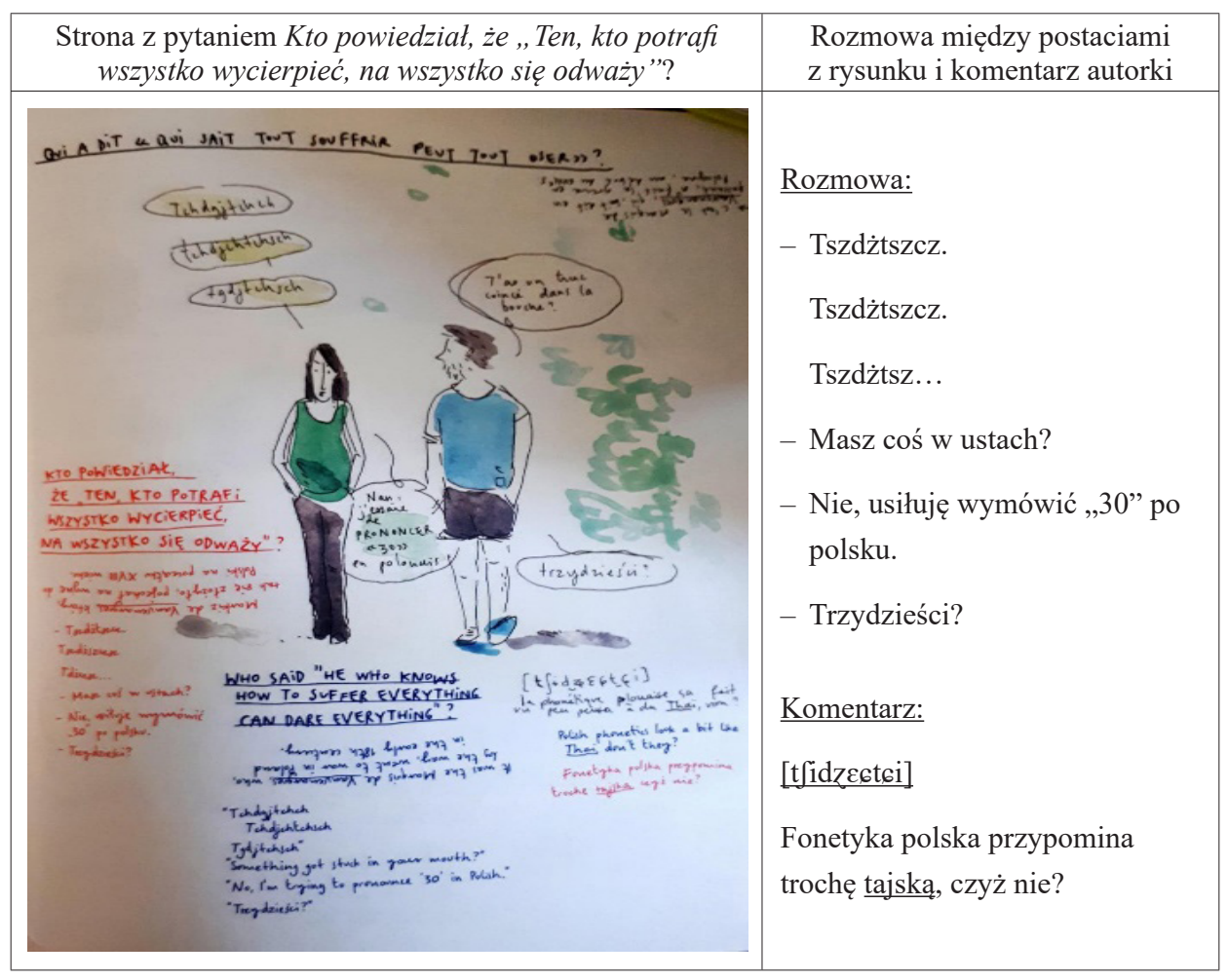

Źródło: Vaucher 2016, s. 77

Polskie pigułki to - w swojej formie - faktycznie ,pigułkowe” odkrywanie polskości. Wymaga ono od odbiorcy dużo więcej zaangażowania w odczytanie specyfiki tego, co jest przedstawiane, niż w przypadku dwóch pozostałych analizowanych tu pozycji, w których autorzy zamieścili obszerniejsze komentarze. Może jednak właśnie z tego powodu potencjał interpretacyjny wpisów F. Vaucher jest większy, mobilizuje bowiem do głębszego, międzykulturowego konfrontowania różnych zjawisk i próby zrozumienia, dlaczego jedne rzeczy nas dziwią czy nawet szokują, a w pozostałych nie widzimy nic osobliwego. Próbom zrozumienia towarzyszy nie mniej ważne pytanie o to, czy i na ile jesteśmy gotowi, aby rozmaite odmienności tolerować.

\section{PODSUMOWANIE I KONKLUZJE}

Omówione w artykule publikacje to nie tylko ważne świadectwa mające wpływ na wizerunek Polski i Polaków wśród obcokrajowców. Ich analiza dowodzi, że perspektywa cudzoziemców w odbiorze polskiej lingwa- i socjokultury 
jest czynnikiem o bardzo dużym znaczeniu w badaniach nad zasobem naszych emblematów kulturowych i z pewnością nie można jej pomijać. Konfrontacja naszych rodzimych sądów i przekonań z cudzoziemskimi doświadczeniami może wpłynąć w istotny sposób na obiektywizację przekonań kulturowych i hierarchizację zjawisk, które mają potencjał emblematu.

Każda $\mathrm{z}$ analizowanych tu książek to swoista próba weryfikacji polskich „miejsc znaczących” w obliczu wartości obecnych w kulturach poszczególnych autorów (por. Kajak 2020, s. 162). W procesie negocjowania znaczeń kulturowych neutralizacji ulegają postawy skrajne i najbardziej subiektywne - zarówno te typowe dla „tubylców” w danej kulturze, jak i jej „przybyszów”. Jednocześnie nie dochodzi (przynajmniej nie powinno) do uogólniania znaczeń, czyli ich schematyzacji, która jest typowa dla mechanizmu powstawania stereotypów. Należy przy tym pamiętać, że ów subiektywizm czy skrajność w postrzeganiu realiów wynika nie tylko z bycia „tubylcem” lub ,przybyszem” - czynnikami równie istotnymi są tutaj wszystkie indykatory socjologiczne, które mogą determinować nasze postrzeganie. Dowodem na to są dane kulturowe zarejestrowane i zaprezentowane przez każdego z omawianych tu autorów, w tym szczególnie znamienny ,alfabet Möllera" - zestaw opracowany przez cudzoziemca o najdhuższym (i najbardziej różnorodnym) stażu w zakresie doświadczania specyfiki polskich realiów. Równie istotne jest także to, iż przywołani w artykule autorzy świadomie wykorzystali „dyplomatyczny” potencjał humoru, aby stworzyć platformę do prezentowania znaczeń kulturowych i dzięki niej neutralizować ryzyko postrzegania swojej postawy jako deprecjonującej czy negującej inność opisywanej kultury. Należy więc stwierdzić, że cudzoziemcy będący przewodnikami i mediatorami kulturowymi to bez wątpienia cenni informatorzy oraz potrzebni partnerzy badań w kulturoznawstwie glottodydaktycznym.

Analizowane publikacje wykazały również, że intencją ich autorów było pokazanie przede wszystkim tych aspektów kulturowych, których poznanie i „oswojenie" ma pomóc cudzoziemcom łatwiej i lepiej funkcjonować w codziennych realiach, nie zaś wprowadzać ich w przestrzeń tzw. kultury wysokiej. Potwierdza to obserwacje płynące $\mathrm{z}$ wcześniejszych badań glottodydaktyków polonistycznych wskazujące na to, że perspektywa przyjmowana w kanonach opracowywanych przez specjalistów w zakresie nauczania jpjo jest odmienna niż ta wyłaniająca się z refleksji cudzoziemców (Zarzeczny, Piekot 2010). Doświadczenia codzienności są w badanym materiale istotne jako te, które prawdopodobnie mają złagodzić mentalne trzęsienie ziemi przy pierwszym kontakcie z rzeczywistością Innych. Ale opisana perspektywa cudzoziemców, którzy zadają pytanie „Gdzie ja jestem?" inspiruje także tubylców do postawienia sobie takiego samego pytania - o rozumienie miejsca, w którym żyją.

Swoje rozważania zakończę przywołaniem jednego z przykazań znajdującego się w klasycznym już dla polskiej glottodydaktyki zestawie D. Piriego zatytu- 
łowanym Dziesięcioro przykazań dla nauczyciela języka polskiego jako obcego. D. Pirie mówi w tym przykazaniu o potrzebie obecności cudzoziemców w gronie nauczycieli języka polskiego - uważam, że stwierdzenie to można z powodzeniem rozszerzyć także na sferę objaśniania polskiej przestrzeni kulturowej, do czego jest nam potrzebna także perspektywa obcokrajowców:

Polak nie zawsze lepiej umie/wie: rodzimy Polak na pewno dobrze potrafi mówić po polsku, ale rzadko kiedy umie pożytecznie wyjaśnić studiującym konkretne problemy. Nie-Polak, który opanował język polski, jest potrzebnym elementem w kręgu nauczycielskim.

(Pirie 1997, s. 16)

\section{BIBLIOGRAFIA}

Amsellem G., 2006, L'imaginaire polonais : Société, culture, art, littérature, Paryż.

Augustynowicz Ch., 2017, Kleine Kulturgeschichte Polens. Vom Mittelalter bis zum 21. Jahrhundert, Wiedeń.

Bralczyk J., 2004, Leksykon zdań polskich, Warszawa.

Bralczyk J., 2005, Leksykon nowych zdań polskich. Od lat 70. do dziś, Warszawa.

Bralczyk J., 2006, Polak potrafi. Przystowia, hasta i inne polskie zdania osobne, Warszawa.

Bralczyk J., 2007, 444 zdania polskie, Warszawa.

Chojnowski P., 2012, Jak Amerykanie postrzegają Polaków i dlaczego ucza się języka polskiego? Studium przypadku, w: K. Filipowicz-Tokarska, P. Chojnowski (red.), Bariery i/ jako wyzwania w nauczaniu języka polskiego jako obcego, Słubice, s. 31-42.

ESOKJ - Europejski system opisu kształcenia językowego: uczenie się, nauczanie, ocenianie, 2003, Warszawa.

Fosso S., 2001, Czarnoskóry student w Europie, Wrocław.

Gębal P., 2005, O Polsce w Unii Europejskiej czy o zachowaniu się podczas ceremonii religijnych? Znajomość których elementów kultury oraz jakich realiów oczekują cudzoziemcy. Raport z przeprowadzonych badań, w: P. Garncarek (red.), Nauczanie języka polskiego jako obcego i polskiej kultury w nowej rzeczywistości europejskiej, Warszawa, s. 234-243.

http://pilulespolonaises.blogspot.com/ [20.03.2020].

http://www.steffen.pl [09.04.2020].

https:/viva.pl/ludzie/newsy/steffen-moller-co-robi-teraz-czy-wroci-do-europa-da-sie-lubic121028-r1/ [09.04.2020].

https://www.polskieradio.pl/9/396/Artykul/336074,Dwa-polskie-swiaty-okiem-obcokrajowca [30.03.2020].

Kajak P., 2020, Kultura popularna w nauczaniu polszczyzny jako języka polskiego. Wstęp do kulturoznawstwa glottodydaktycznego, Warszawa.

Klos Sokol L., 2010, Shortcuts to Poland, Warszawa.

Möller S., 2006, Polska da się lubić. Mój prywatny przewodnik po Polsce i Polakach, Poznań.

Möller S., 2013, Berlin-Warszawa-Express. Pociag do Polski, Poznań.

Möller S., 2019, Weronika, twój mąż tu jest! - Gdy Niemcy i Polacy się kochaja, Poznań.

Niewiara A., 2014, Od polskich słów do polskich zdań. W poszukiwaniu słów kluczy do polskiej kultury, „Forum Lingwistyczne”, nr 1, s. 65-75.

Ornat D., 2013, O polskim przekładzie hiszpańskich kulturemów, w: I. Kasperska, A. Żulechowska (red.), Przekład jako akt komunikacji kulturowej, Poznań, s. 167-194. 
Pirie D., 1997, Dziesięcioro przykazań dla nauczyciela języka polskiego jako obcego (JPJO), w: W.T. Miodunka (red.), Nauczanie języka polskiego jako obcego. Materiaty z I konferencji polonistów zagranicznych i polskich zwołanej z inicjatywy Grupy ,Bristol” do Instytutu Polonijnego UJ, Kraków, s. 13-15.

Rak M., 2015, Kulturemy podhalańskie, Kraków.

Schulze D., Gawin I., 2015, KulturSchock Polen, Reise Know-How, Bielefeld.

Stępień A., Kajak P., 2016, „Let's talk about sex” po polsku. Tabu seksualności w praktyce glottodydaktyki polonistycznej, w: A. Małyska, K. Sobstyl (red.), Tabu w procesie globalizacji kultury, Lublin, s. 141-164.

Swan O., 2014, Kaleidoscope of Poland. A cultural encyclopedia, 2015.

Vaucher F., 2016, Pilules polonaises 2, Warszawa.

Zarzeczny G., Piekot T., 2010, Inny punkt widzenia - treści kulturowe w podręcznikach oczami cudzoziemców, w: P. Garncarek, P. Kajak, A. Zieniewicz (red.), Kanon kultury w nauczaniu języka polskiego jako obcego, Warszawa, s. 199-206.

Zarzycka G., 2004, Lingwakultura - czym jest, jak ją badać i „otwierać”, w: A. Dąbrowska (red.), Wrocławska dyskusja o języku polskim jako obcym, Wrocław, s. 435-443.

Zarzycka G., 2008a, Kultura, lingwakultura, socjokultura w nauczaniu języka polskiego jako obcego, w: A. Seretny, E. Lipińska (red.), Rozwijanie i testowanie biegłości w języku polskim jako obcym, Kraków, s. 143-160.

Zarzycka G., 2008b, Opis pedagogiki zorientowanej na rozwój kompetencji i wrażliwości interkulturowej, w: W.T. Miodunka, A. Seretny (red.), W poszukiwaniu nowych rozwiąań. Dydaktyka języka polskiego jako obcego u progu XXI wieku, Kraków, s. 63-78.

Zarzycka G., 2019, Kulturemy polskie - punkty widzenia, techniki ich wydobywania i negocjowania. Stosowanie perspektywy etnoligwistycznej $w$ glottodydaktyce polonistycznej, „Acta Universitatis Lodziensis. Kształcenie Polonistyczne Cudzoziemców", t. 26, G. Zarzycka, B. Grochala, I. Dembowska-Wosik (red.), s. 425-441. https://doi.org/10.18778/0860-6587.26.29

\title{
Magdalena Smoleń-Wawrzusiszyn
}

\section{POLISH CULTURE EMBLEMS FROM THE PERSPECTIVE OF FOREIGNERS}

Keywords: glotto-cultural studies, Polish culture, emblem, perspective of foreigners

\begin{abstract}
The aim of the article is to present the foreign reception of features and emblematic phenomena of Polish lingua- and socioculture based on the analysis of three guide books: S. Möller's 2006, L. Klos Sokol's 2010 and F. Vaucher's 2016 one, and to assess the usefulness of this type of sources in the search for typical elements of our cultural portrait. The analysis of the publications in question was one of the stages of research (as part of the Emblems of Polish culture - the lexicon concept project) on various perspectives in the perception of the specificity of broadly understood Polishness, the knowledge of which is necessary in the work on extracting and negotiating phenomena that can obtain the status of Polish culture emblems. The presented considerations show, among others, that an important benefit of reception of cultural experiences of foreigners is their "innovative" view of phenomena usually resulting from well-developed intercultural skills. Foreigners can be valuable cultural mediators, especially when in the process of getting accustomed to otherness they are able to explain it with a humorous distance, which helps to build bridges between cultures.
\end{abstract}

